\title{
Hemispheric Organization of Visual Word Recognition in Turkish Monolinguals
}

\section{Півкульова організація візуального розпізнавання слів турецьких одномовних респондентів}

\author{
Filiz Mergen ${ }^{1}$ \\ Ph.D. in Linguistics, \\ Lecturer
}

\author{
Філіз Мерген ${ }^{1}$ \\ кандидат філологічних наук, \\ викладач
}

\section{E-mail: filiz.mergen@ieu.edu.tr orcid.org/0000-0002-9583-9153}

\section{Gulmira Kuruoglu}

Ph.D. in Linguistics, Professor

\section{Гульміра Куруоглу}

кандидат філологічних наук, професор

\section{E-mail: gulmira.kuruoglu@deu.edu.tr orcid.org/0000-0002-4172-0253}

${ }^{1}$ University of Economics, Vocational School, Department of Applied English and Translation $\triangle 156$, Sakarya Caddesi Str., Balcova-Izmir, Turkey, 35330

${ }^{2}$ Dokuz Eylul University, Faculty of Letters, Department of Russian

Langanage and Literature

$\triangle 144$, Cumhuriyet Blv, Kültür Mahallesi, Konak-İzmir, Turkey, 35220
${ }^{1}$ Університет економіки, професійно-технічний заклад, кафедра прикладної англійської мови і перекладу $\triangle$ вул. Сакарія Кадессі, 156, Балкова-Ізмир, Турція, 35330

2 Університет Докуз Ейлул, факультет листування, кафедра російської мови та літератури $\triangle$ бульвар Кумхурієт, 144, Округ Культур Махалессі, Конак-Ізмир, Турція, 35220

Original manuscript received September 02, 2018

Revised manuscript accepted March 01, 2019 
Hemispheric Organization of Visual Word Recognition in Turkish...

\begin{abstract}
Recently obtained data from interdisciplinary research has expanded our knowledge on the relationship between language and the brain considerably. Numerous aspects of language have been the subject of research. Visual word recognition is a temporal process which starts with recognizing the physical features of words and matching them with potential candidates in the mental lexicon. Word frequency plays a significant role in this process. Other factors are the similarities in spelling and pronunciation, and whether words have meanings or are simply letter strings. The emotional load of the words is another factor that deserves a closer inspection as an overwhelming amount of evidence supports the privileged status of emotions both in verbal and nonverbal tasks. It is well-established that lexical processing is handled by the involvement of the brain hemispheres to varying degrees, and that the left hemisphere has greater involvement in verbal tasks as compared to the right hemisphere. Also, the emotional load of the verbal stimuli affects the specialized roles of the brain hemispheres in lexical processing.

Despite the abundance of research on processing of words that belong to languages from a variety of language families, the number of studies that investigated Turkish, a language of Uralic-Altaic origin, is scarce. This study aims to fill the gap in the literature by reporting evidence on how Turkish words with and without emotional load are processed and represented in the brain. We employed a visual hemifield paradigm and a lexical decision task. The participants were instructed to decide if the letter strings presented either from the right or the left of the computer screen were real words or non-words. Their response times and accuracy of their answers were recorded. We obtained shorter response times and higher accuracy rates for real words than non-words as reported in the majority of studies in the literature. We also found that the emotional load modulated the recognition of words, supporting the results in the literature. Finally, our results are in line with the view of left hemispheric superiority in lexical processing in monolingual speakers.
\end{abstract}

Key words: Monolingual, word recognition, emotion words, lateralization, visual hemifields.

\title{
Introduction
}

With the emergence of cognitive science, there has been great interest in how monolingual speakers process language in the brain. Particularly in the field of psycholinguistics and neurolinguistics, lexical, grammatical, phonological and processing of either visually or auditorily presented verbal stimuli has been investigated via numerous methods. An enormous amount of data from a variety of language families exist in the literature. However, to the best of the authors' knowledge, there are very few studies that investigated Turkish language from 
a psycholinguistic perspective, which is spoken as a native language and being learned as a foreign / second language by millions of people today. The existing literature generally focuses on language pathology (Sadiyeva, 2004; Maviş \& Özbabalık, 2006; Toğram, Çıkan \& Duru, 2013; Ulusoy \& Kuruoğlu, 2013), language learning and acquisition (Haznedar, 2007; Dolgunsöz \& Sarıçoban, 2016; Tok \& Yıgın, 2013; Sarıca, 2014; Özge, Marinis \& Zeyrek, 2015) and bilingualism (Belet, 2009; Çeltek, 2014; Mergen \& Kuruoğlu, 2016; 2017). This study aimed to fill this gap in the literature by investigating lexical processing in Turkish, how emotional workload affect lexical processing of Turkish words and their hemispheric organization.

Visual word recognition is a temporal process, whereby the physical features of words, letters, graphemes, phonemes, morphemes, and semantic features are analyzed (Balota, Yap \& Cortese, 2006). Word recognition models in the literature define this process as an autonomous system which involves a series of stages. The first and the widely accepted model is Morton's (1969, 1980) Logogen Model, which predicts visual and auditory input systems and a verbal output system. When the lexical information in each of these systems pass the activation threshold, the word is recognized (Barber \& Kutas, 2007). This model was followed by Serial and Activation Models. The former holds that word recognition proceeds in a series until the best candidate is matched with the target word (Lupker, 2005). The latter, on the other hand, suggests a facilitation or inhibition of the candidates depending on the similarity between their physical features and those of the target word (McClelland \& Rumelhart, 1981). Next generation models are known as Parallel Distributed Models, according to which the ties between units are strengthened with time and frequency of use, thus enabling the target word to be recognized easily (Seidenberg, 1995). Unlike the previous models, there is no lexicon in this model, against which the target word compared and contrasted with the possible candidates. Word recognition takes place by information update of the linguistic information based on the statistical analysis of the input as words are encountered and used over time (Barber \& Kutas, 2007).

According to the prominent models in the literature, some factors influence the word recognition process. Previous work highlight the importance of frequency of use (Larsen, Kimberley, Mercer \& Balota, 
2006; Yap \& Balota, 2009; Rozin, Berman \& Royzman, 2010; Garcia, Garas \& Schweitzer, 2012), orthographic neighbors (Andrews, 1997), phonological similarity (Yates, Locker \& Simpson, 2004) and being a real or a non-word (Jordan, Patching \& Milner, 2000; Jordan \& Patching, 2003; Lavidor, Hayes, Shillcock \& Ellis, 2004). Later research has shown that valence, i.e. words' being positive, negative or neutral, also exerts considerable influence on lexical processing. Experimental studies give a great deal of support to this finding (Kuchinke, Jacobs, Grubich, Vo, Conrad \& Herrmann, 2005; Hofmann, Kuchinke, Tamm, Vo \& Jacobs, 2009; Kousta, Vinson \& Vigliocco, 2009; Schacht \& Sommer, 2009a; Palazova, Mantwill, Sommer \& Schacht 2011). However, there is no conclusive data as to the nature and extent of this influence. For example, one line of research holds that, regardless of valence, emotional load of words affect lexical processing (Kousta, Vinson \& Vigliocco, 2009), while, on the other hand, another maintains that positive valence is processed faster and more accurately than negative and neutral valence (Kissler \& Koessler, 2011; Briesemeister, Kuchinke \& Jacobs, 2011; Palazova et al., 2011). The latter view, known as Positivity Effect, is associated with our evolutionary background and based on the idea that the brain prioritizes positive stimuli. Studies that used emotional words (Briesemeister et al., 2011; Kuchinke et al., 2005; Kissler, Herbert, Winkler \& Junghofer, 2009; Scott, O’Donnell, Leuthold \& Sereno, 2009; Kissler \& Koessler, 2011; Palazova et al., 2011) or pictures (Schacht \& Sommer, 2009b) as stimuli, and electrophysiological (Kissler et al., 2009) and imaging literature (Kuchinke et al., 2005) provide support for this view.

A similar evolution-based assumption holds true for negative valence (LeDoux \& Phelps, 2004). According to this view, negative stimuli are easily and rapidly detected. However, processing it takes longer because as it engages our attention in case it involves threat to our survival. This phenomena, known as the Automatic Vigilance Hypothesis in the literature, makes it difficult for us to disengage our attention and direct it to novel stimuli, thus lengthening the processing time (Estes \& Adelman, 2008). Similar view was introduced by Taylor (1991) in the Mobilization-Minimization Hypothesis, which maintains that negative stimuli are detected in two stages. The former is the mobilization stage in which the organism rapidly catches the negative 
stimuli while in the latter, i.e. minimization, it detaches from or replaces it with something else to ensure the survival. There is good deal of evidence from the literature in support of this view (Kuchinke et al., 2005; Borkenau \& Mauer, 2006; Estes \& Adelman, 2008).

It is unanimously accepted that there is a division of labor between the brain hemispheres and that the left hemisphere is predominantly responsible for language processing (Frost et al., 1999; Hellige, 2001; Lieberman, 2002; Dehaene, Le Clec'H, Poline, Le Bihan, \& Cohen, 2002; McCandliss, Cohen \& Dehaene, 2003; Sommer, Aleman, Bouma \& Kahn 2004; Hugdahl, 2005; Barber \& Kutas, 2007; Nalçac1, 2010). Although a number of reasons for this dominance have been suggested, the evolution-based view that specialization of functions in the brain hemispheres would lessen the competition between the hemispheres, thus increase the chances of the survival of the organism is the most widely accepted one (Toga \& Thompson, 2003). Another view is that the left hemisphere is more suitable to language processing as opposed to the right hemisphere, thanks to its neuroarchitecture (JungBeeman, 2005; Fassbinder \& Tompkins, 2006; Nalçac1, 2010).

After Broca's seminal paper on the superiority of the left hemisphere in language processing, a bulk of research has been done. It was revealed in the imaging literature that the area known as Planum Temporale, part of Wernicke's area is larger than its homologue in the right hemisphere, and this finding has been taken as evidence for left hemispheric dominance in language tasks (Lieberman, 2002; Toga \& Thompson, 2003; Hugdahl, 2005). Also, dichotic listening studies in which the verbal stimuli presented to the right ear are processed faster than when presented to the left ear added further support for left hemisphere superiority (Hugdahl, 2005). Similarly, Wada tests, split brain studies and neuroimaging data all strengthen the idea that the left hemisphere is specialized for language processing (Frost et al., 1999; Hellige, 2001; Hugdahl, 2005). Finally, word recognition literature confirmed these results (Brysbaert, Vitu \& Schroyens, 1996; Deason \& Marsolek, 2005). Particularly, evidence from visual hemifield studies provided solid data that the mental lexicon is situated in the left hemisphere (Babkoff, Faust \& Lavidor, 1997; Jordan, Patching \& Milner, 2000; Deason \& Marsolek, 2005). 


\section{The Present Study}

\section{Participants}

Fifty-three monolingual speakers of Turkish (17 males, 36 females) participated in the study. The mean age of the participants was 28.25 $($ std $=7.32$, min: 18, max: 45).

The candidates were given an eligibility questionnaire which involved queries on age, hand preference, and health problems such as any neurological disorders or visual problems. As a result of the evaluation of the candidates' responses, fifty-three right-handed monolingual speakers who had no history of neurological disorders were selected. They had normal or corrected-to-normal vision. Their hand preference was assessed by Edinburgh Handedness Inventory (Oldfield, 1971), and those who score above 70 out of 100 were accepted for the study $(95.60 \%)$. They gave their signed consent for participating in the study.

\section{Method}

A lexical decision task was used in the study. The participants were instructed to decide if the visually presented letter strings were real words or non-words, and press on the designated keys (key 1, for yes and key 2, for no) with their right hand as fast as possible. The experiment took part in a quiet, dimly-lit room. The participants were seated $40 \mathrm{~cm}$ away from a laptop computer and rested their chins on a chin rest to avoid any head movements. They were told to read the instructions that appeared on the screen and were supplied with explanations by the experimenter where necessary. A trial with 20 words was carried out to familiarize them with the test, but the results were excluded from the statistical analysis. Also, they were asked to give feedback about the trial session.

The stimuli were presented on a $3 \times 1.8 \mathrm{GHz}, 16.5$-inch HP laptop computer with $1024 \times 768$ screen resolution. The task started with a warning sound. Then, a cross emerged in the center and stayed on the screen for $1000 \mathrm{~ms}$. Next, the target word appeared either on the right or the left of the fixation point for $200 \mathrm{~ms}$. The stimuli were presented vertically at a 2-degree angle from the right or left of the screen in a 
random order. Finally, there came a mask to prevent any afterimage. The participants' reaction times and the accuracy of the answers were recorded via SuperLab 4.0 software program and SPSS 18.0 was used to analyze the data.

\section{Stimuli}

A total of 60 words and non-words was used as stimuli. The real words were chosen from a pool of 300 words from Yazllı Türkçe'nin Kelime Sikliğı Sözlüğü (Göz, 2003), and rated by Turkish native speakers $(\mathrm{N}=100)$ on a 5-point Likert Scale according to their valence, frequency of use and the degree of arousal. The ratings were analyzed, and 10 positive, 10 negative and 10 neutral words were selected from the pool. A one-way ANOVA revealed no significant differences between the words in terms of frequency of use $\left(F_{2,27}=0.83, p>.05\right.$, $\left.\mathrm{y}^{2}=.058\right)$ and their degree of arousal $\left(F_{2,27}=1.13, p>.05, \mathrm{y}^{2}=.077\right)$. However, they differed significantly in terms of valence $\left(F_{2,27}=98.01\right.$, $\left.p<.001, \mathrm{y}^{2}=.879\right)$. Thirty non-words were created by exchanging the initial letters and final letters of the real words, and they were all phonologically and orthographically legal words in Turkish. The official web site of Turkish Language Society was checked and it was ensured that none of them had any acceptable meaning in Turkish.

\section{Results}

Response times (RT) below $250 \mathrm{~ms}$ and those above $1800 \mathrm{~ms}$. were discarded from the statistical analysis. As the data were normally distributed, a Paired Samples $t$-Test was conducted. The accuracy of the responses were analyzed based on the number of correct responses within the time permitted. Due to the variation in the proportion of the words and non-words for each participant as a result of response time selection, individual accuracy rates were calculated, and a nonparametric test (Wilcoxon test) was performed on the data.

First, the participants' lexicality judgements were analyzed. Table 1 shows the response times for real words in Turkish and non-words.

As seen in Table 1, the participants' responses for real words are shorter than those for non-words. The diffeence between the response times are statistically significant. 
Hemispheric Organization of Visual Word Recognition in Turkish...

Table 1. Response Times for Real Words and Non-Words

\begin{tabular}{lccccc}
\hline & N & Mean $(\mathbf{m s})$ & Std. & $\boldsymbol{t}$ & $\boldsymbol{p}$ \\
\hline Real Words & 30 & 535.22 & 60.70 & -14.517 & $.000^{*}$ \\
Non-words & 30 & 656.26 & & & \\
\hline
\end{tabular}

$*_{p}<.001$

Next, we examined the accuracy of the responses. Table 2 shows the accuracy rates for real words and non-words.

Table 2. Accuracy Rates for Real Words and Non-Words

\begin{tabular}{lccccc}
\hline & N & Mean (\%) & Std. & $\boldsymbol{Z}$ & $\boldsymbol{p}$ \\
\hline Real Words & 30 & 83 & .10 & & \\
Non-words & 30 & 61 & .19 & -5.79 & $.000 *$ \\
\hline$*_{p}<.001$ & & & &
\end{tabular}

A Wilcoxon Test revealed that the participants responded to real words more accurately than non-words. The difference was found statistically significant.

Our second hypothesis was whether the valence of the words would have any effect on the speed and accuracy of the responses. To this end, we analyzed the response times for words with different valence. The results can be seen in Table 3 .

Table 3. Response Times for Words with Different Valence

\begin{tabular}{llcccc}
\hline \multicolumn{1}{c}{ Turkish Words } & N & Mean $(\mathbf{m s})$ & Std. & $\boldsymbol{t}$ & $\boldsymbol{p}$ \\
\hline Positive Words & 10 & 491.06 & 78.57 & -6.972 & $.000^{*}$ \\
Negative Words & 10 & 566.30 & & & \\
Positive Words & 10 & 491.06 & 65.03 & -6.409 & $.000^{*}$ \\
Neutral Words & 10 & 548.31 & & & \\
Negative Words & 10 & 566.30 & 71.77 & 1.825 & .074 \\
Neutral Words & 10 & 548.31 & & & \\
${ }^{*} p<.001$ & & & & &
\end{tabular}

A Paired Samples $t$-Test revealed that fastest response times were for the positive words, followed by neutral words. It was seen that it took the longest for the participants to recognize negative words. 
Півкульова організація візуального розпізнавання слів турещььких...

To reveal any differences in the recognition of words with different valence, we analyzed the accuracy of the responses. The results are given in Table 4.

Table 4. Accuracy Rates for Words with Different Valence

\begin{tabular}{lccccc}
\hline \multicolumn{1}{c}{ Turkish Words } & N & Mean (\%) & Std. & $\boldsymbol{Z}$ & $\boldsymbol{p}$ \\
\hline Positive Words & 10 & 88 & .13 & -1.873 & .061 \\
Negative Words & 10 & 83 & .14 & & \\
Positive Words & 10 & 88 & .13 & -3.042 & $.002 * *$ \\
Neutral Words & 10 & 81 & .14 & & \\
Negative Words & 10 & 83 & .14 & -1.162 & .245 \\
Neutral Words & 10 & 81 & .14 & & \\
\hline
\end{tabular}

$* p<.001$

According to Table 4, the highest accuracy rates belong to the positive words. However, only the difference between the positive and neutral words were statistically significant.

Finally, we examined how the Turkish words are represented in the brain hemispheres. A Paired Samples $t$-Test was performed to analyze the response times and the accuracy rates for words presented to the right and left hemifields.

The results obtained from the analysis of response times can be seen in Table 5.

Table 5. Response Times for Turkish Words Presented to the Right and Left Visual Fields

\begin{tabular}{lccccc}
\hline & Mean $(\mathbf{m s})$ & Std. & $\boldsymbol{t}$ & $\boldsymbol{d f}$ & $\boldsymbol{p}$ \\
\hline Right Visual Field (Left Hemisphere) & 505.59 & 72.93 & -6.96 & 52 & $.000^{*}$ \\
Left Visual Field (Right Hemisphere) & 564.85 & 52.46 & & & \\
\hline
\end{tabular}

${ }^{*} p<.0001$

As can be seen in Table 5, the words presented to the right visual field have shorter response times than those presented to the left visual field. This result shows that the left hemisphere (LH) is faster in recognizing words than the right hemisphere $(\mathrm{RH})$.

The accuracy rates of the words presented to the right and left visual fields are given in Table 6 . 
Hemispheric Organization of Visual Word Recognition in Turkish...

Table 6. Accuracy Rates for Turkish Words Presented to the Right and Left Visual Fields

\begin{tabular}{lcccc}
\hline & Mean (\%) & Std & $\boldsymbol{Z}$ & $\boldsymbol{p}$ \\
\hline Right Visual Field (Left Hemisphere) & 83.62 & .12 & -.066 & .948 \\
Left Visual Field (Right Hemisphere) & 83.11 & .13 & & \\
\hline
\end{tabular}

$p>.05$

A Wilcoxon Test revealed no statistically significant difference between the words presented from the right and the left visual fields, which can be interpreted as similar performance in recognizing words in either hemisphere.

\section{Discussion}

The point of departure in our study was to investigate the lexical processing of Turkish words, the effect of valence in processing and the brain representations of the words. First, we examined the lexicality judgements of Turkish monolinguals. Response time data revealed a statistically significant difference between the real words and non-words, and the analysis of the accuracy rates supported this result.

Experimental research on word recognition has consistently shown that real words are processed faster and more accurately than non-words (Mohr, Pulvermüller \& Zaidel, 1994; Lavidor et al., 2004; Kuchinke et al., 2005; Hauk, Davis, Ford, Pulvermüller \& Marslen-Wilson, 2006; Nemrodov, Yuval, Javitt \& Lacidor, 2011). Nemrodov et al. (2011) maintain that both hemispheres are equally competent in distinguishing real words from non-words and that there is a greater activation in both hemispheres in processing non-words. This phenomena is known as Word Superiority Effect. Nemrodov et al. (2011) attribute this effect to the fact that non-words differ from real words in that they have no semantic associations in the mental lexicon despite being orthographically legal words. In support for this view, Kuchinke et al. (2005) attribute this to the recruitment of more cognitive resources. The results obtained in our study add further support to the widely accepted view in the literature.

To investigate whether the valence of words have any effect in processing of the visually presented words, we analyzed the 
response times and accuracy rates of positive, negative and neutral words separately. Response time data revealed that positive words were processed faster than both negative and neutral words. Also, no significant difference between the response times of negative and neutral words was found. Accuracy rates, however, partially support these results. We discuss these findings below.

We reported faster response times for positive words as compared to negative and neutral words. This result is consistent with previous evidence regarding the Positivity Effect phenomena, which is associated with the brain's tendency to prioritize positive stimuli in order to increase the chances of survival and well-being (Kuchinke et al., 2005; Kissler et al., 2009; Kissler \& Koessler, 2011; Briesemeister, Kuchinke \& Jacobs, 2011; Palazova et al., 2011). Studies which employ verbal (Kuchinke et al., 2005; Kissler et al., 2009; Scott et al., 2009; Kissler \& Koessler, 2011; Palazova et al., 2011; Briesemeister, Kuchinke \& Jacobs, 2011) and non-verbal stimuli, i.e. pictures (Schacht \& Sommer, 2009b) yielded similar results. Also, electrophysiological (Kissler et al., 2009) and neuroimaging studies (Kuchinke et al., 2005) lend support to this view.

The finding that positive words were recognized faster than negative words runs contrary to some research which claims that emotinal load of words facilitate recognition regardless of valence (Kousta, Vinson \& Vigliocco, 2009). However, our results converge with the previous work which attributed a differential status to negative words. In the literature, negative words have been classified differently from positive and neutral words. For example, Sutton and Altarriba (2008) reported that negative words engage cognitive resources to a greater extent, require a more detailed analysis and cause interferences in the lexical retrieval, which, in turn, slow down the processing. As evidenced in the previous work in the literature, longer response times for negative words as compared to positive and neutral words were reported. For example, in the Estes and Adelman study (2008), in which some confounding factors that influence word recognition such as word length, frequency of use, orthographic neighbors and the degree of arousal were controlled, it was reported that the response times for negative words were longer than positive words. This result was taken as evidence for the greater engagement of attentional resources. Similarly, Kissler and Koessler (2011) reported longer response times and less accuracy for negative 
words, but, associated this result with failing to disengage attention from negative stimuli and direct it to novel stimuli. Larsen, Mercer, Balota and Strube (2008), on the other hand, attributed the differential status of negative words to their frequency of use, degree of arousal and the relative differences in their perception by people.

Slower processing of negative words in our study can be explained on evolutionry grounds. It is well-established in the literature that quick responses to threatening stimuli is critical to our survival (LeDoux \& Phelps, 2004). The supporters of this view maintain that negative stimuli are detected rapidly, but require a detailed analysis as they may be threatening for the organism (Taylor, 1991). However, this analysis may be time-consuming, effortful for the brain, and lead to slower processing of the stimuli (Kuchinke et al., 2005; Borkenau \& Mauer, 2006; Estes \& Adelman, 2008). The response time analysis in our study is in line with the predictions of the Automatic Vigilance Hypothesis in the literature.

When we look at the accuracy rates for positive, negative and neutral words, we see that it is only the difference between the positive and neutral words that reach the level of significance. The difference in accuracy rates between positive and negative words and those between negative and neutral words weren't found significant. This result partially supports the response times. We have two explanations for this result. One could be accuracy-response time tradeoff phenomena (Bogacz, Wagenmakers, Forstmann \& Nieuwenhuis, 2010) which assumes that participants make a choice between speed and accuracy of their responses in experimental tasks. In line with this view, our participants favored faster response times over accurate answers. Another explanation could be the lexical properties of the words in the stimuli set. In stimuli selection process, native speakers of Turkish rated the words according to their frequency, valence and the degree of arousal. Concreteness was not controlled for. Bearing in mind that positive and negative words describe emotional phenomena and that they are less concrete as compared to neutral words, the concreteness effect may account for this result.

Finally, we analyzed how Turkish words are organized in the brain hemispheres. The results from the response time analysis showed that the words presented to the right visual field (RVF) were processed faster than those presented to the left visual field (LVF). According 
to the cross organization in the brain hemispheres, this result can be interpreted as left hemisphere (LH) dominance in lexical processing. When we look at the accuracy rates for words presented to the RVF and LVF, no statistically significant difference was found.

There is a consensus in the literature that the left hemisphere is predominantly responsible for language tasks, particularly in the right-handed monolingual population (Frost et al., 1999; Hellige, 2001; Lieberman, 2002; Toga \& Thompson, 2003; Hugdahl, 2005). It is argued that the neuroarchitecture of the left hemisphere accounts for this superiority (Jung-Beeman, 2005; Nalçac1, 2010). Similarly, a great deal of evidence came from lexical processing studies, which led to the conclusion that the mental lexicon resides in the left hemisphere (Babkoff, Faust \& Lavidor, 1997; Deason \& Marsolek, 2005). Activation in the Fusiform Gyrus in the occipitotemporal area in the left hemisphere strengthened these findings (Dehaene et al., 2002; McCandliss, Cohen \& Dehaene, 2003). Greater involvement of the left hemisphere in visual word processing as compared to the right hemisphere reported in electrophysiological studies confirm the role of the left hemisphere in language processing (Barber \& Kutas, 2007). Our results obtained from the analysis of the response time data are in line with the prevalent view in the literature.

The analysis of the accuracy rates, however, doesn't fully support the response times. Our results show that the participants performed equally well when the words were presented from both visual fields. We explain this finding with accuracy-response time tradeoff phenomena (Bogacz et al., 2010) In line with this view, our participants favored faster response times over accurate answers, which led to no observable difference between the hemispheres.

\section{Conclusion}

The present study aimed to investigate visual word recognition in Turkish and its brain organization.

First, the speed and the accuracy rates of the real words and nonwords were analyzed. The results showed that real words in Turkish are processed faster and more accurately, which is a finding that replicates the Word Superiority Effect phenomena in the literature. 
Secondly, we investigated whether the valence of the words would exert any influence on lexical processing. We analyzed the response times and the accuracy rates for positive, negative and neutral words. The results revealed that positive words were processed faster and more accurately than negative and neutral words. This result is in line with the Positivity Effect phenomena in the literature, which maintains that the human brain is inherently more inclined to positive stimuli due to its evolutionary background. Another important finding is that we obtained longer response times for negative words as compared to positive words. This finding is interpreted as the potential of negative words to engage the attentional resources and delay the processing time. An interesting finding is that no significant difference was found in the response times and the accuracy rates between the positive and negative words and between the negative and neutral words. This was explained by the participants' choice between speed and accuracy of the responses. Another explanation may be the concrete nature of the neutral words, which enhanced the participants' recognition of the neutral words as compared to neutral words.

Finally, we investigated the hemispheric organization of Turkish words. The analysis of the response time data demonstrated that the participants processed words faster in the left hemisphere. This result is consistent with the widely accepted view in the literature which holds that the left hemisphere is dominant in language processing. When accuracy rates were analyzed, we saw that the participants performed equally well when the words are presented from either hemisphere. This result was explained by the speed-accuracy tradeoff in which the participants favored speed over the accuracy of their responses.

\section{References}

Andrews, S. (1997). The effect of orthographic similarity on lexical retrieval: resolving neighborhood conflicts. Psychonomic Bulletin \& Review, 4(4), 439-461. https://doi.org/10.3758/BF03214334

Babkoff, H., Faust, M., \& Lavidor, M. (1997). Lexical decision, visual hemifield and angel of orientation. Neuropsychologia, 35(4), 487-495. https://doi.org/10.1016/ S0028-3932(96)00072-3

Balota, D.A., Yap, M.J., \& Cortese, M.J. (2006). Visual word recognition: the journey from features to meaning (a travel update). In M.J. Traxler \& M.A. Gernsbacher (Eds.), Handbook of Psycholinguistics, (pp. 285-375). A.B.D. : Academic Press. 
Barber, H.A., \& Kutas, M. (2007). Interplay between computational models and cognitive electrophysiology in visual word recognition. Brain Research Reviews, 53(1), 98-123. https://doi.org/10.1016/j.brainresrev.2006.07.002

Belet, Ş.D. (2009). İki Dilli Türk Öğrencilerin Ana Dili Türkçeyi Öğrenme Durumlarına İlişkin Öğrenci Veli ve Öğretmen Görüşleri (Fjell İlköğretim Okulu Örneği Norveç). Selçuk Üniversitesi Sosyal Bilimler Enstitüsü Dergisi, 21, 71-85. http://dergisosyalbil.selcuk.edu.tr/susbed/article/view/308

Bogacz, R., Wagenmakers, E.J., Forstmann, B.U., \& Nieuwenhuis, S. (2010). The neural basis of the speed-accuracy tradeoff. Trends in Neuroscience, 33(1), 1-16. https://doi.org/10.1016/j.tins.2009.09.002

Borkenau, P., \& Mauer, N. (2006). Processing of pleasant, unpleasant and neutral words in a lateralised emotional stroop task. Cognition \& Emotion, 20(6), 866877. https://doi.org/10.1080/02699930500348131

Briesemeister, B.B., Kuchinke, L., \& Jacobs, A.M. (2011). Discrete emotion effects on lexical decision response times. PlosONE, 6(8), 1-9. https://doi.org/10.1371/ journal.pone.0023743

Brysbaert, M., Vitu, F., \& Schroyens, W. (1996). The right visual field advantage and optimal viewing position effect: on the relations between foveal and parafoveal word recognition. Neuropsychology, 10(3), 385-395.

Brysbaert, M., \& Dijkstra, V.H. (2006). Changing views on word recognition in bilinguals. URL : https://biblio.ugent.be/input/download?func $=$ downloadFile\&reco rdOId=685459\&fileOId=685554 (29.01.2013).

Çeltek, A. (2014). Türkçenin Yabancı Dil Olarak Çevrimiçi Öğretiminde Bir İzlence Tasarımı. Turkish Studies, 9(3), 451-465. https://doi.org/10.7827/ TurkishStudies.6411

Deason, R.G., \& Marsolek, C.J. (2005). A critical boundary to the left hemisphere advantage in visual word processing. Brain and Language, 92(3), 251-261. https://doi.org/10.1016/j.bandl.2004.06.105

Dehaene, S., Le Clec'H, G., Poline, J.B., Le Bihan, D., \& Cohen, L. (2002). The visual word form area: prelexical representation of visual words in the fusiform gyrus. NeuroReport, 13(3), 321-325. https://doi.org/10.1097/00001756200203040-00015

Dolgunsöz, E., \& Sarıçoban, A. (2016). CEFR and eye movement characteristics during EFL reading: The case of intermediate readers. Journal of Language and Linguistic Studies, 12(2), 238-252.

Estes, Z., \& Adelman, J.S. (2008). Automatic vigilance for negative words in lexical decision and naming: Comment on Larsen, Mercer ve Balota. Emotion, 8(4), 441-444. https://doi.org/10.1037/1528-3542.8.4.441

Fassbinder, W., \& Tompkins, C.A. (2006). Hemispheric differences in word-meaning processing: alternative interpretations of current evidence. Aphasiology, 20(2-4), 110-122. https://doi.org/10.1080/02687030500472397

Frost, J.A., Binder, J.R., $\quad$ Springer, J.A., Hammeke, T.A., Bellgowan, P.S.F., Rao, S.M., \& Cox, W. (1999). Language processing is strongly left lateralized in both sexes: Evidence from fMRI. Brain, 122, 199-208. https://doi.org/10.1093/ brain/122.2.199

Garcia, D., Garas, A., \& Schweitzer, F. (2012). Positive words carry less information than negative words. EPJ Data Science, 1(3), 1-16. https://doi.org/10.1140/epjds3

Göz, İ. (2003). Yazılı Türkçe’nin Kelime Sıklı̆g Sözlüğü. Ankara : Türk Dil Kurumu Yayınları. 
Hemispheric Organization of Visual Word Recognition in Turkish...

Hauk, O., Davis, M.H., Ford, M., Pulvermüller, F., \& Marslen-Wilson, W.D. (2006). The time course of visual word recognition as revealed by linear analysis of ERP data. NeuroImage, 30(4), 1383-1400. https://doi.org/10.1016/j. neuroimage.2005.11.048

Haznedar, B. (2007). Crosslinguistic influence in Turkish-English bilingual first language acquisition: The overuse of subjects in Turkish. In L. Belikova \& Meroni ve M. Umeda (Eds.), Proceedings of the $2^{\text {nd }}$ Conference on Generative Approaches to Language Acquisition, (pp. 124-134). Somerville, MA : Cascadilla Press. http://www.lingref.com/cpp/galana/2/paper1553.pdf

Hellige, J.B. (2001). Hemispheric Asymmetry. What Is Right and What Is Left. U.S.A. : Harvard University Press.

Hofmann, M.J., Kuchinke, L., Tamm, S., Vo, M.L.H., \& Jacobs, A.M. (2009). Affective processing within $1 / 10^{\text {th }}$ of a second: high arousal is necessary for early facilitative processing of negative but not positive words. Cognitive, Affective and Behavioral Science, 9(4), 389-397. https://doi.org/10.3758/9.4.389

Hugdahl, K. (2005). Symmetry and asymmetry in the human brain. European Review, 13(2), 119-133. https://doi.org/10.1017/S1062798705000700

Jordan, T.R., Patching, G.R., \& Milner, A.D. (2000). Lateralized word recognition: assessing the role of hemispheric specialization, modes of lexical access, and perceptual asymmetry. Journal of Experimental Psychology: Human Perception and Performance, 26(3), 1192-1208. https://doi.org/10.1037/0096-1523.26.3.1192

Jordan, T.R., \& Patching, G.R. (2003). Assessing effects of stimulus orientation on perception of lateralized words and nonwords. Neuropsychologia, 41(12), 1693 1702. https://doi.org/10.1016/S0028-3932(02)00326-3

Jung-Beeman, M. (2005). Bilateral brain processes for comprehending natural language. Trends in Cognitive Sciences, 9(11), 512-518. https://doi.org/10.1016/j. tics.2005.09.009

Kissler, J., Herbert, C., Winkler, I., \& Junghofer, M. (2009). Emotion and attention in visual word processing - an ERP study. Biological Psychology, 80(1), 75-83. https://doi.org/10.1016/j.biopsycho.2008.03.004

Kissler, J., \& Koessler, S. (2011). Emotionally positive stimuli facilitate lexical decisions - an ERP study. Biological Psychology, 86(3), 254-264. https://doi. org/10.1016/j.biopsycho.2010.12.006

Kousta, S.T., Vinson, D.P., \& Vigliocco, G. (2009). Emotion words, regardless of polarity have a processing advantage over neutral words. Cognition, 112(3), 473481. https://doi.org/10.1016/j.cognition.2009.06.007

Kuchinke, L., Jacobs, A.M., Grubich, G., Vo, M.L., Conrad, M., \& Herrmann, M. (2005). Incidental effects of emotional valence in single word processing: an fMRI study. NeuroImage, 28(4), 1022-1032. https://doi.org/10.1016/j. neuroimage.2005.06.050

Lavidor, M., Hayes, A., Shillcock, R., \& Ellis, A.W. (2004). Evaluating a split processing model of visual word recognition: effects of orthographic neighborhood size. Brain and Language, 88(3), 312-320. https://doi.org/10.1016/ S0093-934X(03)00164-0

Larsen, R.J., Kimberley, A., Mercer, K.A., \& Balota, D.A. (2006). Lexical characterstics of words used in emotional stroop experiments. Emotion, 6(1), 6272. https://doi.org/10.1037/1528-3542.6.1.62

Larsen, R.J., Mercer, K.A., Balota, D.A., \& Strube, M.J. (2008). Not all negative words slow down lexical decision and naming speed: Importance of word arousal. Emotion, 8(4), 445-452. https://doi.org/10.1037/1528-3542.8.4.445 
LeDoux, J.E., \& Phelps, E.A. (2004). Emotional networks in the brain. In M. Lewis, J. Haviland-Jones (Eds.), Handbook of Emotions, (pp. 157-172). New York : The Guilford Press.

Lieberman, P. (2002). On the nature and evolution of the neural bases of human language. Yearbook of Physical Anthropology, 45, 36-62. https://doi.org/10.1002/ ajpa.10171

Lupker, S.J. (2005). Visual word recognition: theories and findings. URL : http://psychology.uwo.ca/faculty/lupkerpdfs/Lupker,\%202005.pdf (13.10.2012).

McCandliss, B.D., Cohen, L., \& Dehaene, S. (2003). The visual word form area: expertise for reading in the fusiform gyrus. Trends in Cognitive Sciences, 7(7), 293-299. https://doi.org/10.1016/S1364-6613(03)00134-7

McClelland, J.L., \& Rumelhart, D.E. (1981). An interactive activation model of context effects in letter perception: an account of basic findings. Psychological Review, 88(5), 375-407. https://doi.org/10.1037/0033-295X.88.5.375

Maviş, İ., \& Özbabalık, D. (2006). Yaşlılıkta Nörolojik Temelli İletişim Sorunları ve Dil ve Konuşma Terapisi. Anadolu Üniversitesi Sosyal Bilimler Dergisi, 6(1), 1-18 http://hdl.handle.net/11421/420

Mergen, F., \& Kuruoğlu, G. (2016). Türkçe-İngilizce konuşan ikidilli bireylerin ikinci dillerindeki dilbilgisel ve anlamsal işlemlemelerinin karşılaştırılması. Eskişehir Osmangazi Üniversitesi Sosyal Bilimler Dergisi, 17(1), 61-69. https://doi. org/10.17494/ogusbd.12336

Mergen, F., \& Kuruoğlu, G. (2017). A Comparison of Turkish-English Bilinguals Processing of Emotion Words in Their Two Languages. Eurasian Journal of Applied Linguistics, 3(4), 89-98. https://doi.org/10.32601/ejal.460969

Mohr, B., Pulvermüller, F., \& Zaidel, E. (1994). Lexical decision after left, right and bilateral presentation of function words, content words and nonwords: evidence for interhemispheric interaction. Neuropsychologia, 32(1), 105-124.

Mohr, C., Rowe, A.C., \& Crawford, M.T. (2008). Hemispheric differences in the processing of attachment words. Journal of Clinical and Experimental Neuropsychology, 30(4), 471-480. https://doi.org/10.1080/13803390701550110

Nalçacı, E. (2010). Beyin işlevlerinin yanallaşması. In S. Karakaş (Ed.), Kognitif Nörobilimler, (pp. 149-168). Ankara : Nobel Tip Kitapevleri.

Nemrodov, D., Yuval, H., Javitt, D.C., \& Lacidor, M. (2011). ERP evidence of interhemispheric independence in visual word recognition. Brain and Language, 118(3), 72-80. https://doi.org/10.1016/j.bandl.2010.04.004

Oldfield, R.C. (1971). Oldfield Handedness Inventory. Neuropsychologia, 9(1), 97-113. https://doi.org/10.1016/0028-3932(71)90067-4

Özge, D., Marinis, T., \& Zeyrek, D. (2015). Incremental processing in head-final child language: online comprehension of relative clauses in Turkish-speaking children and adults. Language, Cognition and Neuroscience, 30(9), 1230-1243. https:// doi.org/10.1080/23273798.2014.995108

Palazova, M., Mantwill, K., Sommer, W., \& Schacht, A. (2011). Are emotion effects in single words non-lexical? Evidence from event-related potentials. Neuropsychologia, 49(9), 2766-2775. https://doi.org/10.1016/j. neuropsychologia.2011.06.005

Rozin, P., Berman, L., \& Royzman, E. (2010). Biases in use of positive and negative words across twenty natural languages. Cognition, 24(3), 536-548.

Sadiyeva, G. (2004). Beyin hasarı geçiren Türk hastaların dil bozukluklarının dilbilim açısından incelenmesi. Azerbaycan Milli Bilimler Akademisi Dil Enstitüsü, 31, 219-242. 
Hemispheric Organization of Visual Word Recognition in Turkish...

Sarıca, N. (2014). Idiosyncracy in native language acquisition snd linguistic transfer in second language acquisition. International Journal of Language Academy, 2(4), 554-563. https://doi.org/10.18033/ijla.127

Schacht, A., \& Sommer, W. (2009a). Time course and task dependence of emotion effects in word processing. Cognitive, Affective and Behavioral Neuroscience, 9(1), 28-43. https://doi.org/10.3758/CABN.9.1.28

Schacht, A., \& Sommer, W. (2009b). Emotions in word and face processing: Early and late cortical responses. Brain and Language, 69(3), 538-550.

Scott, G.G., O’Donnell, P.J., Leuthold, H., \& Sereno, S.C. (2009). Early emotion word processing: evidence from event-related potentials. Biological Psychology, 80(1), 95-104. https://doi.org/10.1016/j.biopsycho.2008.03.010

Seidenberg, M.S. (1995).Visual word recognition: an overview. Speech, Language, and Communication. In J.L. Miller \& P.D. ve Eimas (Eds.), Handbook of Perception and Cognition, (pp. 137-179). San Diego, U.S.A : Academic Press.

Sommer, I.E.C., Aleman, A, Bouma, A., \& Kahn, R.S. (2004). Do women really have more bilateral language representation than men? A meta-analysis of functional imaging studies. Brain, 127(8), 1845-1852. https://doi.org/10.1093/brain/awh207

Sutton, T.M., \& Altarriba, J. (2008). Emotion words in the mental lexicon. The Mental Lexicon, 3(1), 29-46. https://doi.org/10.1075/ml.3.1.04sut

Taylor, S.E. (1991). Asymmetrical effects of positive and negative events: The mobilization-minimization hypothesis. Psychological Bulletin, 110(1), 67-85. https://doi.org/10.1037/0033-2909.110.1.67

Toga, A.W., \& Thompson, P.M. (2003). Mapping brain asymmetry. Nature Reviews, 4(1), 37-48. https://doi.org/10.1038/nrn1009

Toğram, B, Çıkan, G., \& Duru, H. (2013). İnmeli Bireylerin Üç Türkçe Afazi Testindeki Performansları Arasındaki İlişki: Bir Ölçüt Geçerliği Çalışması. Turkish Journal of Neurology, 19(1), 15-22. https://doi.org/10.4274/Tnd.07279

Tok, M., \& Yıgın, M. (2013). Yabancı Uyruklu Öğrencilerin Türkçe Öğrenme Nedenlerine İlişkin Bir Durum Çalışması. Dil ve Edebiyat Ĕgitimi Dergisi, 8, 132-147.

Ulusoy, S., \& Kuruoglu, G. (2013). Türk Afazili Hastaların Nesne ve Eylem Adlandırma Becerilerinin Dilbilim Açısından İncelenmesi. The Journal of Academic Social Science Studies, 6(1), 1011-1031.

Yap, M.J., \& Balota, D.A. (2009). Visual word recognition of multi-syllabic words. Journal of Memory and Language, 60(4), 502-529. https://doi.org/10.1016/j. jml.2009.02.001

Yates, M., Locker, L., \& Simpson, G.B. (2004). The influence of phonological neighborhood on visual word perception. Psychonomic Bulletin \& Review, 11(3), 452-457. https://doi.org/10.3758/BF03196594

\section{АНОТАЦІЯ}

Дані міждисциплінарних досліджень значно розширили наші знання про зв'язки між мовою і мозком. Різні аспекти мови були предметом цих досліджень. Візуальне розпізнавання слів - це процес, який починається з упізнавання фізичних характеристик слів і зіставлення їх з потенційними кандидатами в ментальному лексиконі. Частота слова відіграє важливу роль у візуальному 
розпізнаванні слів. Іншими фракторами $\epsilon$ схожість в написанні й вимові, а також те, чи мають слова значення або є просто набором літер. Емоційне навантаження слів є ще одним фактором, який заслуговує більш ретельного вивчення, оскільки $\epsilon$ багато доказів ролі емочій як у вербальних, так $і$ в невербальних завданнях. Добре відомо, що лексична обробка відбувається із залученням в тій чи іншій мірі півкуль мозку і що ліва півкуля домінує в лексичній обробці порівняно з правою півкулею. Крім того, емоційне навантаження словесних стимуляторів впливає на спеціалізовану роль півкуль головного мозку в лексичної обробці.

Незважаючи на безліч досліджень, присвячених проблемі обробки слів, що належать до мов з різних мовних родин, кількість досліджень на матеріалі турецької мови, мов урало-алтайського походження, мало. Дане дослідження спрямоване на заповнення цієї прогалини в науковій літературі шляхом отримання даних про те, як турецькі слова з емоційним навантаженням $і$ без нього обробляються і відтворюються в мозку. У дослідженні була використана парадигма візуальної половини поля зору і лексичне завдання. Від респондентів вимагалося вирішити, чи є ланцюжки літер, представлені праворуч або ліворуч на екрані комп'ютера, справжніми словами, чи ні. Час виконання завдань і точність відповідей були запротокольовані. Результати дослідження показали, що відповіді на справжні слова були дані за більш короткий час і з більш високим показником точності, ніж на несправжні слова, що підтверджується більшістю досліджень. Ми також виявили, що емоційне навантаження модулює розпізнавання слів, підтверджуючи результати, оприлюднені в науковій літературі. Насамкінець, наші результати відповідають думці про перевагу лівої півкулі в лексичної обробці у одномовних респондентів.

Ключові слова: одномовність, розпізнавання слів, емочіонні слова, латералізація, візуальна половина поля зору.

\section{Мерген Филиз, Куруоглу Гульмира. Полушарная организация визуального распознавания слов у турецких одноязычных респондентов}

\section{АННОТАЦИЯ}

Данные междисциплинарных исследований значительно расширили наши знания о связях между языком и мозгом. Разные аспекты языка были предметом этих исследований. Визуальное распознавание слов - это прочесс, который начинается с распознавания физических характеристик слов и сопоставления их с потенциальными кандидатами в ментальном лексиконе. Частота слова играет важную роль в этом процессе. Другими факторами являются сходство в написании и произношении, а также то, имеют ли слова значение или являются просто буквенным набором. Эмоциональная нагрузка слов является еще одним фактором, который заслуживает более тщательного изучения, поскольку имеется много доказательств роли эмоций как в вербальных, так и в невербальных задачах. Хорошо известно, что лексическая обработка 
Hemispheric Organization of Visual Word Recognition in Turkish...

происходит вовлечением в той или иной степени полушарий мозга и что левое полушарие в большей степени вовлечено в речевые задачи по сравнению с правым полушарием. Кроме того, эмоциональная нагрузка словесных стимуляторов влияет на специализированные роли полушарий мозга в лексической обработке.

Несмотря на множество исследований по обработке слов, принадлежащих к языкам из разных языковых семейств, количество исследований на материале турецкого языка, языков урало-алтайского происхождения, мало. Данное исследование направлено на восполнение этого пробела в научной литературе путем представления данных о том, как турецкие слова с эмоциональной нагрузкой и без нее обрабатываются и представляются в мозге. В исследовании была использована парадигма визуальной половины поля зрения и лексическая задача. От респондентов требовалось решить, являются ли буквенные цепочки, представленные справа или слева на экране компьютера, настоящими словами или нет. Время их ответа и точность ответов были записаны. Результаты исследования показали, что ответы на стимульные слова были даны за более короткое время и с более высоким показателем точности, чем на ненастоящие слова, что подтверждается большинством исследований. Мы также обнаружили, что эмоциональная нагрузка модулирует распознавание слов, подтверждая результаты, опубликованные в научной литературе. Наконеи, наши результаты соответствуют мнению о превосходстве левого полушария в лексической обработке у одноязычных респондентов.

Ключевые слова: одноязычие, распознавание слов, эмоционные слова, латерализация, визуальная половина поля зрения. 